\title{
PERAN HUMAN SPIRIT DALAM PENGELOLAAN BANK SAMPAH BERBASISKAN MASYARAKAT DI TANGERANG
}

\author{
Ameilia Chaterina Sari"1), Saparso ${ }^{2)}$ dan Soegeng Wahyoedi ${ }^{3)}$ \\ 1), 2), 3) Program Magister Manajemen Universitas Kristen Krida Wacana, Jakarta \\ 1)ameiliachaterina94@gmail.com \\ 2)saparso @ukrida.ac.id \\ ${ }^{3)}$ swahyoedi@ukrida.ac.id
}

\begin{abstract}
Abstrak
Saat ini permasalahan sampah telah mencapai tahap krisis global dan mengkhawatirkan. Sampah dalam jumlah banyak menjadi polusi baik di darat, laut dan udara yang berdampak merugikan masyarakat. Bank sampah didirikan dengan tujuan mengajarkan dan membiasakan masyarakat untuk menerapkan prinsip 4R (reduce, reuse, recycle, replant) dalam kehidupan sehari-hari. Tahun 2011 pemerintah kota Tangerang membuat program "1.000 bank sampah" menggunakan anggaran 2011/2016 dari Dinas Kebersihan dan Pertamanan (DKP) Kota Tangerang. Bank sampah dibangun dan dikelola warga setempat. Menjelang akhir tahun anggaran 2013, menurut data tercatat hanay ada 120 bank sampah dari rencana 1.000 bank sampah dan hanya 95 bank sampah berfungsi, sementara sisanya tak terkelola baik. Kemudian berdasarkan data yang diperbaharui pada 2017 jumlah bank sampah terdaftar sebanyak 361 di Tangerang. Tujuan penelitian ini adalah melakukan riset kualitatif terkait peran human spirit dalam pengelolaan bank sampah berbasiskan masyarakat di Tangerang. Dari penelitian ini terungkap bahwa peran human spirit sangat dominan dalam pengelolaan bank sampah berbasiskan masyarakat di Tangerang.
\end{abstract}

Kata Kunci: Persepsi Masyarakat, Bank Sampah, Manajemen Sampah

\begin{abstract}
Currently the world's trash crisis has reached the stage of the global crisis and alarming in Indonesia. Lots of trash and garbage becomes environmental pollution on landfill even becomes water and air pollution too, which has have adversely affect the community. Bank Sampah (Waste Banks) were established with the aim of teaching and familiarizing the community to apply the $4 R$ principles (reduce, reuse, recycle, replant) for being a habit formation. In 2011 the government of Tangerang made the "1.000 waste bank" program using 2011/2016 budget of City Sanitation and Landscaping Department (DKP). Waste banks are built and managed by local community. Towards the end of fiscal year 2013, according to the data, there were only 120 waste banks of 1,000 that planned and only 95 were functioning, while the rest were not well managed. Then based on updated data in 2017 there were 361 waste banks are registered at Tangerang. The purpose of this study is to conduct qualitative research that related to the role human spirit of the waste management using the community-based waste banks at Tangerang. The results of this study revealed that the role of human spirit was very dominant in the management of community-based waste banks at Tangerang.
\end{abstract}

Keywords: Community perception, Waste Banks, Waste Management

\section{PENDAHULUAN}

\section{Latar Belakang}

Masalah sampah di seluruh dunia telah mencapai tahap yang mengkhawatirkan. Sampah dalam jumlah banyak menjadi polusi darat, laut, dan udara yang berdampak merugikan masyarakat secara sosial dan ekonomi.

Data Kementerian Lingkungan Hidup dan
Kehutanan (KLHK) menunjukkan adanya tren yang meningkat jumlah sampah plastik yang ada di Indonesia. Sampah tersebut telah mencapai level mengkhawatirkan dalam kurun waktu sepuluh tahun terakhir. Tahun 2018, volume sampah telah mencapai 66,5 juta ton (Kompas.com-26/07/2018).

Hayat dan Hasan (2018) mengatakan meningkatnya nilai konsumsi masyarakat perkotaan dalam memenuhi kebutuhan 
hidupnya, menjadi penyumbang dari semakin banyaknya sampah yang harus dibuang. Sampah rumah tangga tidak dapat dianggap kecil dalam kapasitas penyumbang sampah bagi lingkungan. Pertumbuhan manusia yang setiap tahun meningkat, tidak luput menjadi faktor penyumbang sampah. Sedangkan pengelolaan sampah berbasis masyarakat belum dilakukan secara maksimal.

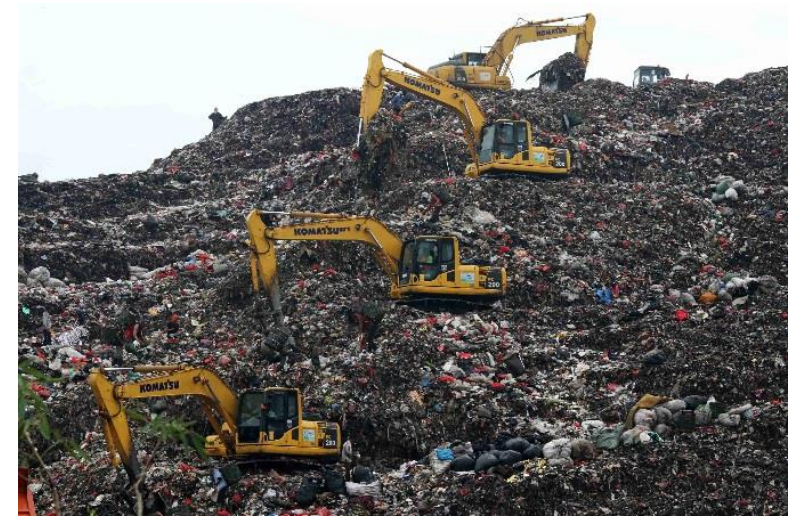

Yunde (2016) mengatakan bahwa peran masyarakat dalam menanggulangi sampah yang diwujudkan dalam kegiatan hak dan kewajiban, memikirkan, merencanakan, melaksanakan dan mengevaluasi programprogram kemasyarakatan tergolong rendah. Peranan masyarakat dalam menanggulangi sampah masih belum maksimal. Faktorfaktor yang mempengaruhi keterlibatan masyarakat dalam menanggulangi sampah masih tergolong rendah dan sistem pengelolaan sampah masih terbilang kurang memuaskan.

Data hasil riset Jambeck (2015), menyebutkan Indonesia berada di peringkat kedua penyumbang sampah ke laut yang mencapai 187,2 juta ton. China menempati peringkat pertama dan Filipina peringkat ketiga. Penelitian selanjutnya oleh Sustainable Waste Indonesia (SWI) (2017) menyatakan bahwa 1) $24 \%$ sampah di Indonesia masih tidak terkelola, 2) Dari sekitar 65 juta ton sampah yang diproduksi setiap hari, ada sekitar 15 juta ton mengotori ekosistem dan lingkungan, 7\% didaur ulang dan $69 \%$ berakhir di Tempat Pembuangan Akhir (TPA).

Dari data laporan SWI (2017) diketahui juga jenis sampah yang paling banyak dihasilkan adalah sampah organik sebanyak 60 persen, sampah plastik (14\%), diikuti sampah kertas (9\%), metal (4,3\%), kaca, kayu dan bahan lainnya (12,7\%) (CNN Indonesia-25/04/2018).

Sampah permukiman, yaitu sampah rumah tangga berupa sisa pengolahan makanan, perlengkapan rumah tangga bekas, kertas, kardus, gelas, kain, sampah kebun dan lain-lain (Gelbert et. al., 1996). Kota Tangerang adalah sebuah kota yang terletak di Provinsi Banten, Indonesia. Kota ini terletak tepat di sebelah barat ibu kota negara Indonesia, Jakarta. Tangerang merupakan kota terbesar di Provinsi Banten serta ketiga terbesar di kawasan Jabodetabek setelah Jakarta dan Bekasi di provinsi Jawa Barat. Sebagai kota perbatasan dengan Jakarta, maka banyak pekerja Jakarta yang tinggal di Tangerang. Kondisi ini membawa konsekuensi menumpuknya sampah di Tangerang yang kemudian menjadi salah satu masalah serius di Tangerang.

Menurut Agus Sudrajat, Kepala Dinas Kebersihan, Pertamanan, dan Pemakaman (DKPP) Kota Tangerang, kendala pengelolaan sampah adalah pada minat masyarakat dan kebiasaan masyarakat membuang sampah di sungai sulit berubah. Untuk itu, menurut Aulia, anggota DPRD Kota Tangerang, mengatakan bahwa butuh kesabaran dari DKPP untuk menghadapi sikap dan kebiasaan warga yang belum peduli dengan pengolahan sampah (Kompas.com-31/10/2018).

Berdasarkan hasil observasi dan wawancara peneliti pada akhir tahun 2018 dengan pengelola bank sampah yang tersebar di Tangerang sebagai narasumber, didapatkan data mengenai jumlah pelanggan nasabah, bagaimana proses layanan bank sampah, dan bagaimana jalinan hubungan organisasi dengan instansi pemerintah. Jumlah pelanggan atau nasabah bank sampah yang didapatkan adalah 500 orang nasabah dari 5 bank sampah yang peneliti kunjungi.

Dari wawancara peneliti dengan narasumber, terlihat bahwa kebanyakan bank sampah didirikan dan dikelola oleh sekelompok wanita berusia sekitar 30-50 tahun dan ada pula sebagian bank sampah yang dikelola oleh sekelompok pemudapemudi berusia sekitar 20-30 tahun. Keseluruhan bank sampah yang menjadi narasumber data penelitian ini merupakan 
unit bank sampah tingkat RT/RW. Target nasabahnya adalah warga yang tinggal di wilayah perumahan tersebut. Cara yang digunakan untuk menarik warga supaya bergabung menjadi pelanggan yaitu dengan mensosialisasikan saat tatap muka langsung, mengundang warga mengikuti acara bertema pengembangan kreativitas, acara edukasi untuk mengubah sampah menjadi bernilai ekonomis, himbauan melalui rapat lingkungan $\mathrm{RT}$, dan melalui kegiatan Pembinaan Kesejahteraan Keluarga (PKK) setempat.

Berdasarkan informasi dari semua narasumber mengenai pembiayaan modal dan kebutuhan operasional bank sampah didukung penuh oleh Dinas Lingkungan Hidup. Sedangkan sistem manajemen, promosi, dan layanan pelanggan adalah hasil inisiatif dari pengelola bank sampah yang ditentukan secara mandiri, artinya tidak ada Standar Operasional Prosedur (SOP) resmi dari pemerintah selaku organisasi yang mencanangkan program bank sampah kepada pelaku pasar.

\section{Tujuan Penelitian}

Bank sampah yang berbasiskan partisipasi warga perempuan merupakan modal sosial dalam pengelolaan sampah berbasis masyarakat. Menurut Asteria (2015) Perubahan paradigma masyarakat mengenai sampah perlu dilakukan secara berkelanjutan. Edukasi kesadaraan dan keterampilan warga untuk pengelolaan sampah dengan penerapan prinsip reduce, reuse, recycle dan replant (4R) penting dalam penyelesaian masalah sampah melalui pengelolaan sampah sejak dari sumbernya.

Dengan demikian tujuan penelitian ini mengukur kinerja pengelola bank sampah melalui persepsi berbasiskan masyarakat di Tangerang, apakah pengelola bank sampah sudah mampu membangkitkan human spirit yakni pengetahuan pelanggan, memenuhi perasaan atau emosi dan spiritual pelanggan mengenai permasalahan sampah.

\section{TINJAUAN PUSTAKA}

\section{Kemanusiaan (Human Spirit)}

Human Spirit dalam perspektif Islam berdasarkan konsep marketing menurut Kunaifi (2015) mengatakan bahwa:

"Human Spirit merupakan sifat kemanusiaan yang dimiliki oleh manusia secara alamiah dan merupakan sifat-sifat universal. Sifat yang komprehensif antara nilai materi dan non materi, yang mendorong suatu aktivitas pemenuhan kebutuhan manusia (ekonomi) secara sempurna. Pemenuhan yang mampu memuaskan kebutuhan jasmani, naluri, pikiran, dan spiritual. Aplikasi konsep tersebut akan melahirkan sebuah produk yang memiliki utility maksimum (rasional) dan menentramkan hati (emosional dan spiritual)."

Menurut Zohar (Kotler et. al., 2010:20) mengatakan masyarakat kreatif selalu mencoba memperbaiki diri mereka dan dunianya. Hal ini yang diadaptasi ke dalam ilmu marketing oleh Kartajaya (2017) dengan menyatakan:

"Filosofi Ikigai terdiri dari empat faktor utama. Pertama, passion for knowledge, kebutuhan untuk menemukan pengetahuan. Kedua, passion for business, yakni hasrat untuk berusaha. Ketiga, passion for service, adanya dorongan untuk melayani orang lain. Keempat, passion for people, kebutuhan untuk memuliakan orang lain. Bentuknya bisa hobi atau kegiatan yang membahagiakan"

Saat ini masyarakat semakin mencari sumber spiritual di atas pemenuhan materi. menurut Kotler, Kartajaya, Setiawan (2010) menyebutkan bahwa:

"Sebagai hasil dari peningkatan tren ini di masyarakat, konsumen tidak lagi mencari jasa dan produk yang memenuhi kebutuhan mereka, namun juga mencari pengalaman dan model bisnis yang menyentuh sisi spiritual mereka. Memberikan meaning adalah value proposition dalam marketing masa depan."

Hakikat manusia pada dasarnya terbagi menjadi delapan sifat dan karakter manusia 
yaitu: 1) kemampuan menyadari diri, 2) kemampuan bereksistensi, 3) kata hati (consecience of man), 4) moral, 5) tanggung jawab, 6) rasa kebebasan, 7) kewajiban dan hak, dan 8) kemampuan menghayati kebahagiaan.

Pada konsep citizen 4.0 oleh Kartajaya (2017) terdapat empat fase kehidupan sepanjang hidup manusia yaitu: 1) fundamental life-stage yang berlangsung pada dua puluh tahun pertama kehidupan, 2) forefront life-stage yang terjadi pada rentang usia 20-40 tahun, 3) foster life-stage yaitu terjadi saat seseorang berusia 40-60 tahun dan 4) final life-stage yaitu tahap kehidupan terakhir terjadi pada saat berusia 60-80 tahun.

Setiap fase terdapat proses dan pola pikir yang berbeda. Pada fase pertama ada banyak hal yang pertama kali ditemui, dipelajari, dan dilakukan yang bermanfaat bagi seluruh fase berikutnya. Fase kedua mulai ada tindakan berupaya mewujudkan kemampuan terbaik, harapan menghasilkan finansial memuaskan dan membangun reputasi. Pada fase ketiga mulai ada kesadaran diri untuk memberikan dukungan supaya orang lain lebih sukses dalam kehidupannya dan keinginan membawa manfaat pada orang lain. Akhirnya pada fase terakhir ada pengalaman hidup yang panjang, kebijaksanaan, dan menghargai momen dalam hidup. Inti kehidupan adalah bagaimana mengisi keempat tahapan hidup tersebut agar benar-benar berarti (Kartajaya, 2017).

Berdasarkan pernyataan di atas dapat dikatakan bahwa pelanggan mengambil keputusan dalam tindakannya ditentukan oleh pikiran rasional, emosi, dan kecerdasan spiritualitas yang ada dalam dirinya dan memberi mendorongan atau motivasi untuk melakukan perubahan perilaku agar membawa dampak baik agar memenuhi keinginannya dalam membangun hubungan dengan dirinya sendiri (secara lahir dan batin) dan dengan semua hal di luar dirinya seperti hubungan dengan sesama, lingkungan, dan makhluk hidup lainnya secara luas.

\section{Bank Sampah}

Presiden RI ke-7, Joko Widodo mendorong terobosan pengelolaan sampah secara terpadu dan sistemik. Oleh karena itu pada tahun 2016 Kementerian Kehutanan dan Lingkungan Hidup mencanangkan program 'Indonesia Bersih 2020' ditandatangani oleh stakeholders yang terdiri dari unsur pemerintah daerah (Bupati/Walikota), unsur pengusaha (Kadin), organisasi keagamaan seperti Nahdatul Ulama, Parisada Hindu Darma, Perwakilan Umat Buddha Indonesia (WALUBI) dan unsur masyarakat (LSM) lainnya pemerintah menjalankan program bank sampah sebagai realisasi program tersebut dan bekerja sama dengan Kementerian Koordinator Bidang Kemaritiman dan Kementerian Pekerjaan Umum dan Perumahan Rakyat.

Bank sampah dijalankan berdasarkan Undang-Undang (UU) No. 18 tahun 2008 tentang pengelolaan sampah atau memilah sampah adalah kegiatan yang sistematis, menyeluruh, dan berkesinambungan yang meliputi pengurangan dan penanganan sampah yang bertujuan untuk meningkatkan kesehatan masyarakat dan kualitas lingkungan serta menjadikan sampah sebagai sumber daya. Pengelolaan atau memilah sampah rumah tangga dan sampah sejenis sampah rumah tangga terdiri atas pengurangan sampah dan penanganan sampah.

Dimana pengurangan sampah yang dimaksud meliputi kegiatan pembatasan timbulan sampah, pendauran ulang sampah, dan pemanfaatan kembali sampah. Sedangkan sejak tahun 2011 pemerintah kota Tangerang membuat program 1.000 bank sampah menggunakan anggaran anggaran 2011/2016. Bank sampah dibangun di tingkat RT/RW, sekolah, dan kantor Pemkot yang dikelola warga setempat. Menjelang akhir tahun anggaran 2013, jumlah bank sampah yang terbangun baru 120 bank sampah dari rencana 1.000 bank sampah dan hanya 95 bank sampah berfungsi, sementara sisanya tak terkelola baik.

\section{ANALISIS DAN PEMBAHASAN}

Krisis biasanya membawa ide atau konsep baru dalam dunia bisnis. Ada delapan hal yang menjadi sumber ide inovasi kewirausahaan. Tren (trends) bisa berupa perubahan sosial, teknologi, ekonomi ataupun kepemerintahan, kemudian sumber 
ide inovasi yang berasal dari peristiwa tidak terduga (unexpected occurrences), ketidaksesuaian (incongruities) yang terjadi antara ekspektasi dan realita, adanya kebutuhan dalam memproses sesuatu (process needs), perubahan industri dan pasar (industry and market changes), perubahan demografi (demographic changes), perubahan persepsi akan sesuatu (perceptual changes), adanya peningkatan dalam pengetahuan (knowledge-based concepts) yang melahirkan adanya metode baru (Kuratko, 2017).

Penelitian ini menggunakan konsep pemasaran dengan pendekatan human centric marketing dan bertujuan untuk menciptakan pertumbuhan pelanggan atau nasabah bank sampah karena jika program bank sampah ini berhasil, maka besar potensinya untuk dapat mengatasi permasalahan lingkungan dan mencapai tujuan pembangunan Sustainability Development Goals (SDGs). Dalam website United Nations (disebut Peserikatan BangsaBangsa atau PBB dalam Bahasa Indonesia) menjelaskan SDGs adalah 17 tujuan dengan 169 capaian yang terukur dan tenggat yang telah ditentukan oleh sebagai agenda dunia pembangunan untuk kemaslahatan (kebaikan) manusia dan planet bumi (www.un.org).

Untuk mengetahui apakah terdapat kebenaran secara empiris peran human spirit dalam pengelolaan bank sampah berbasiskan masyarakat di Tangerang dalam mewujudkan visi dan misi mengatasi permasalahan sampah dan lingkungan dan mendukung Sustainability Development Goals menciptakan lingkungan yang bersih dan sejahtera.

Pertama pelanggan perlu memiliki pengetahuan mengenai dampak negatif sampah. Menurut Alex (2012) menjelaskan apabila pengelolaan sampah yang tidak dilakukan secara sistematis, menyeluruh, dan berkesinambungan maka akan dapat menimbulkan berbagai dampak negatif sebagai berikut:

“1) Dampak terhadap kesehatan yaitu lingkungan yang kotor menjadi tempat berkembang biak organisme yang dapat menimbulkan berbagai penyakit, meracuni hewan dan tumbuhan yang dikonsumsi oleh manusia. 2) Dampak terhadap lingkungan yaitu menyebabkan mati atau punahnya flora dan fauna serta menyebabkan kerusakan pada unsurunsur alam seperti terumbu karang, tanah, perairan hingga lapisan ozon. 3) Dampak terhadap sosial ekonomi yaitu menyebabkan bau busuk, pemandangan buruk yang sekaligus berdampak negatif pada pariwisata secara bencana seperti banjir."

Kedua pelanggan dengan pengetahuan mengenai dampak negatif dari sampah yang tidak terolah secara emosional menyadari masalah ini mempengaruhi kehidupannya. Melalui program bank sampah pelanggan akan dibimbing mengembangkan sikap masyarakat kreatif yang bertanggung jawab, berorientasi kembali kepada lingkungan, dan penerimaan diri dalam bagian komunitas.

Ketiga pelanggan secara spiritual akan menyadari bahwa sebagai manusia sesungguhnya akan merasakan kebahagiaan dalam bentuk memiliki kesadaran diri, membuktikan eksistensi diri, memiliki moral untuk menjaga ciptaan di bumi, memenuhi kewajiban dan hak terhadap segala ciptaan, memberi manfaat bagi orang lain, merasakan kebahagiaan, kebebasan, rasa aman dan nyaman. Adanya harapan untuk masa depan saat dirinya sudah tidak ada lagi di dunia ini.

Maka akhirnya human spirit muncul dan menjadi konsep pemasaran masa depan yang dipertimbangkan dari sudut pandang perjalanan perkembangan era marketing. Berdasarkan penelitian yang telah dilakukan yaitu peran human spirit dalam pengelolaan bank sampah berbasiskan masyarakat di Tangerang dapat dijelaskan bahwa human spirit berpengaruh signifikaan terhadap aktivitas menabung sampah pada bank sampah dijelaskan pada sifat dasar pada hakikat manusia sebagai berikut:

1. Kemampuan menyadari diri

Kemampuan menyadari diri sendiri, adalah kemampuan manusia menjadi dirinya sendiri. Dalam artian yang lebih luas manusia harus mampu dan mengembangkan apa yang ada dalam dirinya demi kemanusiaannya. Mampu mengembangkan aspek sosialitasnya dan mampu juga mengembangkan aspek individualitasnya sehingga jika manusia dapat menyeimbangkan kedua aspek tersebut maka dengan begitu 
manusia mampu mengekplorasi potensipotensi yang ada serta membuat jarak dengan yang lainnya.

Teori ini diperkuat oleh pernyataan dari Ibu Widhi, pengelola bank sampah Kemuning yang saat ditanya bagaimana proses berdiri bank sampah di lingkungan menyatakan bahwa:

"Pertama kali mengetahui bank sampah adalah dari program pemerintah, kemudian saya pada tanggal 4 Januari 2015 menghimbau kepada warga untuk membuat bank sampah di lingkungan kita. Pada awalnya kita ingin pemuda yang menjadi pengurusnya namun karena pemudanya banyak yang sibuk pada akhirnya ibu-ibu yang meng-handle sampai sekarang. Bangunan gudang untuk bank sampah ini dibuat melalui swadaya masyarakat."

Kemudian ada tanggapan dari lbu Mulyadi, nasabah bank sampah Kemuning yang menyatakan:

"Tanggapan saya mengenai bank sampah ini bagus karena bisa membersihkan lingkungan, kita juga dapat bersosialisasi dengan warga lainnya melalui bank sampah ini, kita juga dapat mengisi waktu luang dan menghasilkan uang."

Tidak hanya kesadaran diri sebatas membuat bank sampah saja. Para pengelola bank sampah memiliki kesadaran diri dalam berupaya untuk melaksanakan kegiatan bank sampah agar menjadi teratur dan berkelanjutan. Ibu Ismi, Bank Sampah Kampung Hijau Barokah mengatakan:

"Dalam menjalankan bank sampah, kalau dari sistemnya kami independen, rasanya pemerintah hanya mengawasi saja seperti "oh masih ada bank sampahnya, yaudah lanjutkan", seperti itu. Pemerintah juga memberikan beberapa fasilitas seperti buku tabungan tapi masih kurang karena nasabah lebih banyak, kalau dari sistem penjualanya kita menjualnya ke pengepul sampah di daerah Alam Sutera jadi mereka seperti pabrik daur ulang."
2. Kemampuan bereksistensi

Kemampuan bereksistensi adalah pernyataan bahwa manusia itu ada dan mengetahui apa yang ada di luar dirinya. Kemampuan bereksistensi berarti manusia mampu membuat jarak antara dirinya sebagai makhluk egosentris dengan dirinya secara obyektif. Di mana pun dan dalam kondisi apa pun manusia harus mampu menyatakan keeksistensiannya agar tidak terpengaruh dengan yang lainnya. Dengan kemampuan bereksistensi, manusia pun mampu melihat obyek sebagai sesuatu yang diamatinya menjadi sesuatu yang berguna dengan akal pikirannya. Selain itu, manusia juga dapat menerobos ruang dan waktu tanpa harus merubah segala hal yang ada pada dirinya.

Teori ini diperkuat oleh pernyataan dari narasumber ketika ditanya berapa orang nasabah saat ini. Ibu Imelda, pengelola bank sampah Pusani menyatakan:

"Banyaknya nasabah di tempat ini sekitar 234 orang dan penimbangan dilakukan dalam 2 minggu sekali."

Ibu Nina, pengelola Bank Sampah Cimone Mas Permai II yang menyatakan:

"Jumlah nasabah di bank sampah Cimone Mas Permai II adalah 70 orang dan proses penabungan bisa kapan saja hanya saja penimbangannya setiap hari rabu pukul 08.00-12.00 WIB"

Kemudian diperkuat lagi oleh pernyataan pengakuan masyarakat yang mengakui bahwa bank sampah adalah milik bersama meskipun awal terbentuknya adalah dorongan dari program pemerintah. Namun mereka senantiasa bersedia menunjukkan keberadaan mereka sebagai masyarakat yang peduli dan ingin lingkungan menjadi bersih. Seperti yang disampaikan oleh lbu Yayu dari Bank Sampah Kec. Tangerang yang mengatakan bahwa:

"Pemilik dari bank sampah ini adalah masyarakat tetapi pengelolaannya diatur oleh kecamatan Tangerang." 


\section{Kata hati (consecience of man)}

Pemilikan kata hati atau qalbu menjadikan manusia berbeda dengan binatang dan makhluk lainnya karena manusia memiliki kata hati yang dapat memberikan penerangan tentang perbuatan baik dan buruk. Jika ada sesuatu yang salah maka kata hati akan berbicara, begitu pun sebaliknya. Dengan memiliki kata hati, manusia dapat memberikan bentuk pengertian yang menyertai perbuatan atau membenarkan apa yang dilakukannya tanpa harus terpengaruh oleh hal-hal lain di luar dirinya, namun harus dalam konteks kebenaran umum atau nilai-nilai positif dalam kehidupan.

Teori ini diperkuat oleh pernyataan dari narasumber lbu Ismi, Bank Sampah Kampung Hijau Barokah yang menceritakan bahwa terbentuknya bank sampah sampai dapat beraktivitas dan mengadakan banyak program seperti sekarang ini tidaklah mudah yang akhirnya melibatkan banyak individu yang bersedia dengan kerelaan hatinya turut campur tangan agar program ini bisa terus dilaksanakan, diceritakan oleh beliau dengan mengharukan berikut ini:

"Bank sampah Kampung Hijau Barokah didirikan karena adanya program pemerintah dibawah dinas Lingkungan Hidup dan di laksanakan oleh Alm.ibu Risma Murni. Bank sampah ini berdiri pada 11 Desember 2012, pada awal dulu terbentuknya bank sampah ini, perjalanannya tidak semudah kelihatannya, karena bank sampah ini bersifat independen sehingga pada awal belum memiliki gedung tempat bernaung, jadi bank sampah ini berpindah- pindah dari rumah pengurus satu dan yang lainnya sampai pernah juga diusir oleh warga karena mereka berpikir sampah itu bau. Sampai akhirnya warga mengumpulkan dana berupa materi seperti bahan bangunan untuk membuat bangunan yang sekarang menjadi tempat Bank Sampah ini."

Selain menabung sampah menjadi uang atau materi yang menguntungkan nasabah. Pada setiap bank sampah banyak ditemui program unik lainnya seperti sampah yang ditukarkan dengan sembako. Kemudian sembako tersebut misalkan beras diberikan nasabah ke masjid sebagai bentuk ibadah. Maka ada semboyan "Sampah jadi Berkah" di lingkungan masyarakat. Ibu Ismi, Bank Sampah Kampung Hijau Barokah, Pinang-Kota Tangerang mengatakan:

"Caranya dengan datang "Door to Door" kerumah warga sebanyak 4 blok, dengan mengimingi bahwa sampah dapat ditukarkan dengan uang, kami juga membuat koperasi supaya masyarakat dapat menukarkan sampah dengan sembako. Bank sampah ini juga pernah diundang ke salah satu stasiun tv swasta pada tahun 2016."

4. Moral

Moral atau etika adalah nilai-nilai yang mengatur manusia. Nilai-nilai yang mencakup dua hal, yaitu nilai dasar yang bersifat universal (nilai-nilai kemanusiaan secara umum) dan nilai instrumental yang bersifat bahagian dari nilai-nilai dasar tersebut. Nilai instrumental lebih menekankan kepada cara atau hal yang nampak dalam keumuman nilai dasar. Dengan memiliki moral (etika), manusia mampu membuat jarak antara kata hati dengan moral. Sehingga dapat dikatakan moral manusia terjadi karena adanya dorongan dari kata hati. Jika kata hati berkata baik maka moral manusia itu pun dapat menghadirkan nilai-nilai yang baik. Melalui pendidikan manusia dapat menumbuhkembangkan etiket (sopan santun) dan etika (nilai-nilai kehidupan).

Teori ini diperkuat oleh pernyataan dari narasumber lbu Imelda yang mengatakan bahwa:

"Terkadang pendidikan tinggi dan mobil bagus bukan jaminan untuk tertib buang sampah, karena terkadang beliau juga masih menegur warga yang membuang sampah sembarangan di lingkungan komplek rumahnya."

Menyadari bahwa perilaku tidak mudah untuk diubah, para pengelola bank sampah kreatif menghimbau warga 
dengan berbagai cara da aktivitas. Ibu Widhi, pengelola bank sampah Kemuning menyatakan:

"Kami mengajak warga untuk menjadi nasabah sampah dengan mensosialisasikan dengan bekomunikasi secara langsung saat bertatap muka dan juga melalui rapat RT dan PKK, dan kami juga juga mendatangi ke rumah- rumah warga."

Ibu Nina, pengelola Bank Sampah Cimone Mas Permai II yang menyatakan:

"Cara mengajak warga untuk menjadi nasabah bank sampah ini dimulai melalui pertemuan $\mathrm{RT}$ dan RW dan kita juga beberapa kali menjadi narsumber di acara PKK dalam acara kreatifitas, kami juga membuat koperasi yang menerapkan sistem agar nasabah bisa membeli barang yang dijual di koperasi dari tabungan yang dia punya."

Ibu Yayu, Bank Sampah Kec. Tangerang mengatakan bahwa:

"Cara untuk mengajak masyarakat menjadi nasabah adalah dengan mengadakan acara- acara kreativitas untuk menciptakan barang- barang dari sampah. Kita juga memberikan pengajaran tentang bagaimana cara membuat susuatu yang memiliki nilai ekonomis dari sampah agar masyarakat memiliki kesadaran tentang adanya organisasi bank sampah ini."

\section{Tanggung Jawab}

Tanggung jawab manusia di dunia ini terbagi menjadi tiga bagian, yaitu tanggung jawab kepada diri sendiri, tanggung jawab kepada masyarakat, dan tanggung jawab kepada Tuhan. Namun demikian, tanggung jawab itu bermuara kepada Tuhan sebab manusia diciptakan adalah sebagai bukti pengabdian manusia kepada Tuhannya untuk menjaga atau sebagai khalifah di muka bumi. Tanggung jawab itu sendiri berasal dari moral manusia yang dihadirkan oleh kata hatinya.

Teori ini diperkuat oleh pernyataan dari narasumber Ibu Imelda Hendrawan, pengelola bank sampah Pusani menyatakan:

"Program Pemerintah yang kebetulan saya selaku ketua RT bertanggung jawab sejak dibentuknya bank sampah ini. Bank sampah Pusani ini memiliki kepanjangan "Pungut Sampah Sana Sini" Tempat atau pondoknya ini dahulu tempat sampah tapi karena sampahnya semakin banyak akhirnya dari swadaya masyarakat membangun tempat ini beserta fasilitasnya."

Ibu Nina, pengelola Bank Sampah Cimone Mas Permai II yang menyatakan:

"Supaya bisa meminimalisir sampah yang akan dibuang ke TPA, Pemerintah supaya bisa memfasilitasi bank sampah ini karena dulu bank sampah ini bisa membuat kompos sendiri atau pupuk cair, Warga diharapkan berpartisipasi karena bisa belanja di koperasi menggunakan sampah, Warga komplek supaya bisa tergerak karena masih berfikir kalau sampah cuma hanya dibuang dan diangkut petugas kebersihan saja."

\section{Rasa Kebebasan}

Rasa kebebasan manusia memiliki arti merdeka. Kebebasan bukan berarti manusia harus bebas dari segala tuntutan dalam kehidupan, melakukan semua hal sesuai dengan keinginan dirinya sendiri, namun bebas di sini adalah bebas yang dibatasi oleh rasa. Rasa kebebasan harus sesuai dengan tuntutan kodrat manusia, mampu merubah ikatan luar yang membelenggu menjadi ikatan dalam yang menggerakkan hatinya. Jadi, semua tuntutan yang ada dalam kehidupan harus mampu menyatu dengan dirinya sendiri sehingga manusia dapat bebas menurut kodratnya. Oleh sebab itu, dalam rasa kebebasan (kemerdekaan) manusia dapat mengendalikan kata hatinya agar dapat menciptakan moral yang baik sehingga dapat mempertanggungjawabkan

perbuatannya sesuai dengan rasa kebebasan tersebut. 
Teori ini diperkuat oleh pernyataan dari narasumber lbu Widhi, pengelola bank sampah Kemuning menyatakan:

"Harapan saya untuk bank sampah ini agar nasabah tetap konsisten dalam menabung sampah agar bisa mengurangi sampah yang ada disekitar kita, masyarakat semakin sadar akan sampah, semakin banyak bank sampah disetiap tempat."

Ibu Mulyadi, nasabah bank sampah Kemuning yang menyatakan:

"Bank sampah bisa lebih maju lagi, bisa lebih banyak, pengurus dan warga sekitar semakin kompak bekerja sama dan makin semangat dalam menjaga lingkungan."

\section{Kewajiban dan Hak}

Kewajiban dan Hak manusia berawal sejak dilahirkan Tuhan ke dunia karena memiliki hak hidup sejak manusia itu masih berada di dalam rahim. Namun, hak itu harus dibarengi oleh kewajiban yang merupakan keniscayaan bagi dirinya sebab jika kewajiban tidak ada maka hak adalah sesuatu yang kosong. Kita tak perlu menuntut hak lebih awal jika kewajiban yang dituntut belum dijalankan. Hak itu ada karena kewajiban ada.

Teori ini diperkuat oleh pernyataan dari narasumber lbu Yayu, pengelola bank sampah Tangerang mengatakan bahwa:

"Bank sampah ini berdiri karena adanya program dari pemerintah yang dibuat untuk memudahkan dalam pemilahan sampah agar sampah dapat dicacah dimulai dari RT, RW hingga kecamatan, pencacahan ini dilakukan agar sampah-sampah yang masih memiliki nilai ekonomis dapat dijadikan sebuah seni dari kreativitas setiap orang, sehingga sampah-sampah yang dibawa ke TPA adalah sampah yang benar- benar tidak dapat digunakan lagi dan tidak memiliki nilai ekonomis lagi."
Ibu Nina, pengelola Bank Sampah Cimone Mas Permai II yang menyatakan:

"Bank sampah ini dibuat pada 16 November 2013 karena adanya program pemerintah tentang 1000 bank sampah. Pada awal pembentukan bank sampah ini dalam pemilihan kepengurusannya agak sulit karena kebanyakan warga sibuk sehingga jarang ada di rumah, akhirnya kepengurusan bank sampah ini diserahkan kepada ibu rumah tangga."

Ibu Mulyadi, nasabah bank sampah Kemuning yang turut memberi tanggapan kebahagiaannya mengenai keberadaan bank sampah dan menyatakan bahwa:

"Sangat senang karena dengan bank sampah bisa mendapatkan uang, kita juga medapatkan kegiatan baru dan bertemu orang baru."

Ibu Nina, pengelola Bank Sampah Cimone Mas Permai II yang menggambarkan ada tanggung jawab pemerintah pada masyarakat dan sebaliknya pengelola bank sampah pada pemerintah, beliau menyatakan bahwa:

"bank sampah tidak bekerja sama dengan organsasi lain tetapi langsung di bawah pengawasan dinas lingkungan hidup yang juga sudah memfasilitasi bank sampah ini memberikan mesin pencacah dan beberapa tong sampah, pemerintah juga membantu kami dengan mendirikan bangunan."

8. Kemampuan menghayati kebahagiaan Menghayati kebahagiaan adalah puncak dari sifat hakikat manusia. Menghayati kebahagiaan berarti memadukan antara pengalaman yang menyenangkan dengan yang pahit melalui sebuah proses, di mana hasil yang didapat adalah kesediaan menerima apa 
adanya. Jadi, kebahagiaan itu muncul ketika kejadian atau pun pengalaman sudah dipadukan di dalam hati dan kita mampu menerimanya dengan apa adanya tanpa harus menuntut sedikit pun.

Teori ini diperkuat oleh pernyataan dari narasumber lbu Yayu, Bank Sampah Kec. Tangerang mengatakan bahwa:

"Harapannya agar masyarakat itu tidak hanya memiliki mindset menabung uang tetapi adanya bank sampah ini masyarakat diharapkan untuk memiliki kesadaran untuk juga menyukai menabung sampah, dimana juga menabung sampah memiliki keuntungan- keuntungan tersendiri dan juga membantu mengurangi sampah yang ada disekitar kita. Dengan adanya bank sampah juga ingin menumbuhkan inisiatif agar masyarakat lebih suka untuk membuat barang sendiri dari sampah dibandingkan mereka membeli dengan harga yang mahal karena dengan membuat barang itu juga dapat dijual kembali dan dapat menghasilkan uang."

Ibu Imelda, pengelola bank sampah Pusani yang ditanya mengenai harapannya atas bank sampah di masa depan menyatakan:

"Yang pastinya berharap pemkot dapat lebih memperhatikan tentang Bank Sampah dan Tiap masingmasing RT/RW harus punya bank sampah, dari pihak kepolisian juga ikut turun tangan karena sudah ada perdanya tapi mengapa orang yang buang sampah sembarangan masih bisa dimaklumi, setiap individu harus lebih peka lagi dalam membuang sampah pada tempatnya, Bank sampah semakin maju."

Menurut Liu and Leach (Veno dan Subagio, 2013) menyatakan bahwa apabila terdapat kepercayaan antara pembeli dengan tenaga penjual suatu perusahaan maka akan tercipta suatu kerjasama dalam mengembangkan ide, mencapai tujuan dan mengatasi masalah yang ada.
Swaminathan dan Reddy (Veno dan Subagio, 2013) menyatakan bahwa kepercayaan juga merupakan psychological outcome dari suatu hubungan. Selain membedakan berdasarkan macamnya, Kotler (Pudjiastuti, 2016) memaparkan pembagian produk sosial menjadi beberapa tipe berupa ide, praktik (tindakan dan perilaku) dan objek/benda nyata. Produk sosial berupa ide terdiri dari kepercayaan, sikap dan nilai.

Pada tipe pertama yaitu ide dapat berupa tiga hal yaitu belief, attitude, dan value. Belief diartikan sebagai pembangunan persepsi tentang persoalan nyata, namun tidak mencakup evaluasi. Attitude diartikan pembangunan penilaian positif atau negatif tentang suatu ide dan mencakup tanggapan evaluasi, baik terhadap orang, benda, ideide, maupun kejadian. Sedangkan value atau nilai dapat diinterpretasikan sebagai keseluruhan ide yang benar dan salah. Tipe selanjutnya yakni praktik yaitu produk sosial yang dapat berupa penegakan pola perilaku yang dirubah. Tipe terakhir dari produk sosial adalah objek/benda nyata yang merupakan produk pendukung dalam suatu social marketing.

Berdasarkan penjelasan di atas dapat digambarkan bahwa bank sampah adalah gabungan dari ketiga model produk sosial menurut Kotler (Pudjiastuti, 2016). Pertama bank sampah dibuat berupa tangible object (benda nyata) yang digunakan untuk melakukan praktik sosial menabung sampah. Kedua bank sampah menjadi model praktik, dimana pemilahan sampah dilakukan secara terus menerus dan menjadi perilaku dan tindakan yang terpola. Ketiga bank sampah menjadi value idea bahwa memilah sampah dan menabung sampah adalah kegiatan terpuji yang merupakan tanggung jawab dan memberikan kenyamanan bagi kehidupan.

Human spirit yang terdiri dari pengetahuan, emosional dan spiritual manusia turut terbentuk melalui keadaan lingkungan sehingga produk sosial dalam bentuk bank sampah hadir di Indonesia. Menurut Nursyahbani dan Pigawati (2015) mengatakan bahwa kondisi lingkungan yang buruk menyebabkan penurunan pada kesehatan mental dan kesejahteraan warga. Pada lingkungan yang buruk perilaku warga lebih agresif. sehingga penting untuk mengetahui kenyamanan sosial pada 
permukiman kumuh yang jelas memiliki kondisi lingkungan dibawah standar kesehatan.

Menurut Pudjiastuti (2016:9) produk sosial adalah sesuatu yang dapat ditawarkan ke pasar untuk diperhatikan, diperoleh, digunakan, atau dikonsumsi untuk memenuhi kebutuhan, keinginan, dan harapan masyarakat dalam mengatasi masalah sosialnya. Dalam sosiologi terdapat tiga paradigma, yaitu paradigma fakta sosial, paradigma definisi sosial, serta paradigma perilaku sosial. Kastolani (2016) membahas kesehatan mental manusia adalah wujud keharmonisan dan keserasian jiwa yang dapat memecahkan segala macam persoalan, untuk selanjutnya akan memunculkan kebahagiaan.

Menurut Annanda Sabil (2014) mengatakan bahwa banyak permasalahan yang dihadapi oleh masyarakat disebabkan oleh perilaku individu atau kelompok. Untuk memecahkan permasalahan tersebut diperlukan suatu strategi untuk merubah perilaku individu tersebut. Berkembangnya teori-teori pemasaran dan psikologi serta sosiologi menyebabkan social marketing dapat digunakan sebagai alternative dalam merubah perilaku individu.

Sehingga dibutuhkan manajemen perubahan yang menyangkut pihak pemerintahan, pembangunan karakteristik dalam pendidikan, dan sosial budaya dalam menciptakan perubahan prilaku oleh masyarakat atau pelanggan. Manajemen perubahan menurut Arifin (2017) adalah suatu proses sistematis yang bertujuan untuk mempengaruhi perubahan pada orang, lembaga atau organisasi terutama yang berfungsi sebagai wadah untuk mempersiapkan generasi sekarang agar mampu memberi pengaruh pada masa mendatang.

Sebaliknya manusia percaya jika tidak mengubah perilaku maka masalah tersebut akan berdampak buruk pada kehidupannya, keluarganya, lingkungannya, dan kehidupan orang lain serta makhluk hidup lainnya. Manusia sesungguhnya akan merasa dirinya adalah bagian dari kekacauan dan memiliki sebagian tanggung jawab.

Implikasi dalam menghadapi masalah lingkungan adalah upaya mengolah kekhawatiran dan harapan manusia melalui ide produk sosial bank sampah untuk menjadi program berkesinambungan bersifat perencanaan jangka panjang. Manusia yang kompleks dengan pikiran, hati dan spiritual dapat berkontribusi melaksanakan kewajiban dan tanggung jawabnya terhadap pencipta, diri sendiri, orang lain, lingkungan dan makhluk hidup lainnya. Sebagai gantinya seseorang akan mendapatkan rasa aman, nyaman dan sejahtera melalui tindakan bertanggung jawab mereka sebagai manusia.

Berdasarkan pengamatan peneliti (2019) saat ini perusahaan BUMN telah melaksanakan proses pemilahan sampah dan pengurangan penggunaan plastik. Contohnya disediakan bak sampah terpisah sesuai jenis dan menghimbau karyawannya dengan nilai-nilai $3 \mathrm{R}$ (reduce, reuse dan recycle). Artinya sudah terbentuk dorongan budaya sosial yang mengarah pada perubahan perilaku masyarakat melalui lingkungan hidup sehari-hari seperti lingkungan kerja, sekolah, tempat rekreasi, dll.

Masalah sampah tidak terolah membuat manusia membutuhkan solusi. Ide bank sampah muncul dan diharapkan berkembang dan membawa nilai serta meningkatkan pandangan bagi masyarakat bahwa sampah yang juga memiliki nilai ekonomi. Strategi masa depan menurut Kotler et. al. (2010) untuk mencapai kepuasan pelanggan perlu memahami human spirit dalam diri pelanggan yang mampu menyentuh tidak hanya dalam bentuk kebutuhan fisik saja melainkan juga sisi emosional dan spiritual. Karena kepuasan pelanggan sangat tergantung pada persepsi dan ekspektasi pelanggan, maka organisasi perlu mengetahui faktor-faktor yang mempengaruhi kepuasan pelanggan.

Dibutuhkan analisa terhadap proses psikologis yang mempengaruhi pola pikir dan tindakan dari nasabah saat ini. Sekarang sampah adalah benda yang dipandang memiliki nilai ekonomi. Menurut Kartini Kartono (Kastolani, 2016) terdapat tiga prinsip pokok yang menentukan kesehatan mental, yaitu: 1) pemenuhan kebutuhan pokok, 2) kepuasan, dan 3) posisi dan status sosial.

Pada era ini bumi sedang mengalami krisis global salah satunya adalah permasalahan sampah yang membawa dampak negatif bagi manusia dalam segi 
kesehatan, sosial dan bahkan sisi ekonomi. Organisasi sosial muncul dan tercipta dari alur perkembangan jaman dan masalah yang ada. Tidak hanya tertuju pada kesejahteraan stakeholder and sheareholder saja tetapi juga bagi semua dengan membawa keseimbangan antara solusi dari permaslahan yang digelutinya dan juga nilai ekonomi.

\section{KESIMPULAN}

Berdasarkan hasil analisis penelitian ini dapat disimpulkan bahwa ada pengaruh human spirit terhadap aktivitas pengelolaan bank sampah berbasiskan masyarakat di Tangerang.

\section{DAFTAR PUSTAKA}

Buku

Alex, S. 2012. Sukses mengolah sampah organik menjadi pupuk organik. Sleman: Pustaka Baru Press.

Gelbert, M., Prihanto, D., \& Suprihatin, A. (1996). Konsep pendidikan lingkungan hidup dan "Wall Chart". Buku Panduan Pendidikan Lingkungan Hidup. Malang: PPPGT/VEDC.

Kartajaya, H. (2017). Citizen 4.0: Menjejakkan prinsip-prinsip pemasaran humanis di era digital. Jakarta: Gramedia

Kotler, P., Kartajaya, H., \& Setiawan, I. (2010). Marketing 3.0: Mulai dari produk ke pelanggan ke human spirit. Jakarta: Penerbit Erlangga

Kotler, P., Kartajaya, H., \& Setiawan, I. (2017). Marketing 4.0: Moving from traditional to digital. Hoboken, New Jersey: John Wiley dan Sons, Inc.

Kuratko, D. F. (2017). Entrepreneurship, theory, process, practice. South-Western.

Pudjiastuti, W. (2016). Social marketing strategi jitu mengatasi masalah sosial di Indonesia. Yayasan Pustaka Obor Indonesia.

Jurnal

Arifin, H. Z. (2017). Perubahan perkembangan perilaku manusia karena belajar. Jurnal Dharmawangsa, 2(1).

Asteria, D. (2016). Bank sampah sebagai alternatif strategi pengelolaan sampah berbasis masyarakat di Tasikmalaya. Jurnal Manusia Dan Lingkungan, 23(1).

Hayat \& Zayadi, H. (2018). Model inovasi pengelolaan sampah rumah tangga. Jurnal Ketahanan Pangan, 2(2), 131-141.

Jambeck, J. R., Geyer, R., Wilcox, C., Siegler, T. R., Perryman, M., Andrady, A., \& Narayan, R. (2015). Plastic waste inputs from land into the ocean. Journal of Science, 347, 768-771

Kastolani. (2016). Internalisasi Nilai-Nilai Tauhid Dalam Kesehatan Mental. Interdisciplinary Journal of Communication. Program Doktoral Universitas Kebangsaan Malaysia. 1(1).

Kunaifi, A. (2015). Implementasi pemasaran syari'ah berbasis human spirit dalam islamic finance (Studi kasus strategi pemasaran di BPRS Bhakti Sumekar Kabupaten Sumenep). Jurnal Malia, 7(1).

Nursyahbani, R., \& Pigawati, B. (2015). Kajian karakteristik kawasan pemukiman kumuh di Kampung Kota. Jurnal Teknik $P W K, 4(2)$.

Sabil, A. (2014). Social marketing: Strategi menuju Indonesia lebih baik. [Internet]. Diakses dari: http://sabilfeb.lecture.ub. ac.id/files/2014/03/Social-Marketingfinal.pdf

Trisnowati, J. (2011). Pelayanan publik dan konsep tentang kepuasan pelanggan. fakultas ekonomi. Universitas Surakarta. [Internet]. Tersedia di: http://ejurnal.net/portal/index.php/Smootin g/article/view/869/800 pada tanggal 5 januari 2019.

Veno, M. (2013). Analisa pengaruh kepercayaan terhadap tenaga penjual (Trust in employee), dan kepercayaan terhadap merek (Trust in brand) terhadap niat beli (purchase intention) konsumen pada Bernini furniture di Surabaya, dan Semarang. Jurnal Manajemen Pemasaran Petra. 1(2), 1-12.

Yunde, M. Z. (2016). Peran masyarakat dalam menanggulangi sampah $\mathrm{Di}$ Kelurahan Kamonji Kecamatan Palu Barat. Skripsi. Pendidikan IImu Pengetahuan Sosial. Fakultas Keguruan 
dan Ilmu Pendidikan. Universitas Tadulako: Palu.

Artikel

Badan Penelitian dan Pengembangan Kementrian Dalam Negeri. 26 April, 2018. Riset: 24 Persen Sampah di Indonesia Masih Tak Terkelola. Diunduh dari http://litbang.kemendagri.go.id/website/ris et-24-persen-sampah-di-indonesia-masihtak-terkelola/ tanggal 28 September 2018.

Badan Pusat Statistik. (24 Agustus, 2015). Rata-Rata Volume Sampah Per Hari menurut Kecamatan di Jakarta Barat 2013. Badan Pusat Statistik. Diunduh dari https://jakbarkota.bps.go.id/statictable/201 5/08/24/22/rata-rata-volume-sampah-perhari-menurut-kecamatan-di-jakarta-barat2013.html pada tanggal 28 September 2018.

CNN Indonesia. 25 April, 2018. Riset: 24 Persen Sampah di Indonesia Masih Tak Terkelola. diunduh dari https://www.cnnindonesia.com/gayahidup/20180425101643-282-293362/riset24-persen-sampah-di-indonesia-masihtak-terkelola tanggal 28 September 2018.

Kemaritiman. (9 Oktober, 2017). Kemenko Maritim Bawa Rencana Aksi Nasional Penanganan Sampah Plastik Laut di Konferensi Kelautan Uni Eropa. Kemaritiman. Diunduh dari https://maritim.go.id/kemenkokemaritiman-bawa-rencana-aksi-nasionalpenanganan-sampah-plastik-laut-dikonferensi-kelautan-uni-eropa/ pada tanggal 28 September 2018.

Pitoko, Ridwan. 26 Juli, 2018. Sampah Plastik di Indonesia Jadi Perhatian Presiden Bank Dunia. Kompas.com. diunduh dari https://ekonomi.kompas.com/read/2018/0 7/26/135610326/sampah-plastik-diindonesia-jadi-perhatian-presiden-bankdunia pada tanggal 28 September 2018.

Sucipto, Adi. 2013. Program Bank sampah Pemkot Tangerang Terancam Gagal. https://megapolitan.kompas.com/read/201 3/10/31/0843573/Program.Bank.Sampah. Pemkot.Tangerang.Terancam.Gagalpada tanggal 28 September 2018.
Sampah Plastik Ancam Indonesia, Seberapa Parahkah Kondisinya?. Kompas.com. diunduh dari https://sains.kompas.com/read/2018/04/2 3/190600123/krisis-sampah-plastikancam-indonesia-seberapa-parahkahkondisinya-. pada tanggal 28 September 2018.

Wismabrata, Michael. 23 April, 2018. Krisis 
Sari, et al. / Peran Human Spirit dalam Pengelolaan Bank Sampah ... 